Jurnal Ilmu Ilmu Agribisnis: Journal of Agribusiness Science, 9(2), Mei 2021

\title{
PENGARUH PROGRAM UPAYA KHUSUS TERHADAP PRODUKTIVITAS, BIAYA POKOK PRODUKSI DAN PENDAPATAN USAHATANI KEDELAI DI KABUPATEN LAMPUNG TIMUR
}

\author{
(The Impacts of Upaya Khusus Program on Yield, Production Standard Cost and Profit of Soybean \\ Farming in East Lampung Regency)
}

Fajar Setya Dharma, Agus Hudoyo, dan Achdiansyah Soelaiman

Jurusan Agribisnis, Fakultas Pertanian, Universitas Lampung, J1. Prof. Dr. Soemantri Brodjonegoro No. 1

Bandar Lampung 35141,e-mail : agus.hudoyo@fp.unila.ac.id

\begin{abstract}
This study aims to analyze the impact of the Upsus program on those three variables. The sample of this study were chosen by the simple random sampling method. The total respondents were 66 farmers of soybean from two districts in three villages for each district. They were interviewed for their farm budget in dry season2014 for non-upsus and dry season 2018 for Upsus. Therefore, the total observations were 132. There are three dependent variables, i.e. yield, production standard cost (HPP), and profit. The independent variables were Upsus and location as a control variable. Data were analyzed by the multiple linear regression model. The results of this study revealed that the Upsus program had statiscally significant $(\alpha=1$ percent) impact on increasing the yield, decreasing the production standard cost, and increasing the profit of the soybean farming. Its yield increased 16 percent, i.e. from 1.35 ton/ha to 1.57 ton/ha. Its production standard cost decreased 19 percent, i.e. from IDR4,690/kg to IDR3,820/kg. Its profit increased 57 percent, i.e. from IDR3.21 million/ha to IDR5.05 million/ha.
\end{abstract}

Key words: cost, production, profit, soybean, yield

\section{PENDAHULUAN}

Tanaman pangan merupakan komoditas pertanian yang memiliki peran penting dan strategis, karena pangan merupakan kebutuhan primer yang pemenuhannya merupakan hak asasi dari setiap manusia. Undang-Undang Republik Indonesia Nomor 18 Tahun 2012 tentang pangan menyatakan bahwa, penyelenggaraan pangan di Indonesia bertujuan untuk memenuhi kebutuhan dasar manusia yang dapat memberikan manfaat secara merata, adil dan berkelanjutan berdasarkan kedaulatan pangan, kemandirian pangan dan ketahanan pangannasional. Dalam rangka mewujudkan ketahanan pangan tersebut, Indoneisa harus mandiri dan berdaulat dalam menentukan kebijakan pangan dengan memerhatikan sumber daya yang tersedia.

Kedelai menjadi salah satu komoditas tanaman pangan yang menjadi perhatian khusus pemerintah karena memiliki nilai penting baik dari segi ekonomi, sosial dan budaya serta menjaga stabilitas dan ketahanan pangan nasional. Seiring berjalannya waktu, penggunaan komoditas kedelai di Indonesia kian meningkat. Hal ini disebabkan oleh banyaknya permintaan kedelai yang digunakan untuk konsumsi, baik sebagai bahan makanan, bahan baku industri dan bahan pakan ternak.

Produksi kedelai dalam negeri pada tahun 20142018 secara keseluruhan mengalami defisit kedelai yang sangat banyak. Indonesia sampai saat ini masih memiliki ketergantungan akan impor kedelai karena produksi kedelai di tanah air masih belum cukup untuk memenuhi kebutuhan kedelai dalam negeri. Oleh karena itu, untuk meningkatkan produksi kedelai dalam negeri, pemerintah mengeluarkan program Upaya Khusus (Upsus) Peningkatan Produksi Padi, Jagung dan Kedelai (Pajale).

Menurut Peraturan Menteri Pertanian Nomor 3 Tahun 2015, dalam membantu mencapai target produksi yang telah ditetapkan untuk mencapai swasembada pangan, maka rangkaian kegiatan Program Upsus Pajale terdiri dari pengembangan jaringan irigasi, optimasi lahan, pengembangan System of Rice Intensification, gerakan penerapan pengolahan tanaman terpadu (GP-PTT), optimasi perluasan areal tanam kedelai melalui peningkatan indeks pertanaman (PAT-PIP), perluasan areal tanam jagung, penyediaan sarana dan prasarana pertanian (bibit, pupuk, pestisida, alat dan mesin pertanian), pengendalian organisme pengganggu tanaman (OPT) dan dampak perubahan iklim, 
asuransi pertanian serta pengawalan atau pendampingan.

Menurut Peraturan Kementerian Pertanian Republik Indonesia nomor 03/0T.140/2/2015 tentang pedoman upaya khusus, program Upsus Pajale diharapkan dapat meningkatkan produktivitas kedelai minimal sebesar 1,57 ton per hektar pada areal tanam baru dan meningkatnya produktivitas kedelai sebesar 0,2 ton per hektar pada areal existing sehingga mampu mempercepat tercapainya swasembada pangan secara nasional dan mampu memperbaiki keragaan usahatani khususnya pada komoditas kedelai.

Berdasarkan uraian tersebut, maka penelitian ini memiliki tujuan yaitu menganalisis pengaruh program Upsus terhadap peningkatan produktivitas lahan pada usahatani kedelai, menganalisis pengaruh program Upsus terhadap penurunan biaya pokok produksi usahatani kedelai, dan menganalisis pengaruh program Upsus terhadap peningkatan pendapatan usahatani kedelai.

\section{METODE PENELITIAN}

\section{Lokasi dan Pengumpulan Data}

Metode pengambilan sampel dilakukan dengan menggunakan teknik Simple Random Sampling yang artinya pengambilan sampel yang dilakukan dalam penelitian ini diambil secara acak tanpa melihat dan memperhatikan tingkatan dalam populasi yang akan digunakan.

Sampel yang digunakan dalam penelitian berjumlah 66 sampel yang terbagi dari dua kecamatan yaitu Kecamatan Raman Utara dan Bandar Sribhawono. Karakteristik lokasi dipilih berdasarkan kondisi tanah untuk lokasi 1 (Raman Utara) yang dikategorikan sebagai daerah subur dan lokasi 2 (Bandar Sribhawono) untuk daerah kurang subur. Sampel terdiri dari 33 petani kedelai yang mengikuti Upsus dan 33 petani kedelai yang tidak mengikuti Upsus (Non-Upsus).

Menurut Cohen (2007), semakin besar sampel yang diambil dalam suatu populasi maka hasil yang diperoleh akan semakin baik, namun sampel yang akan digunakan memiliki batas minimal yaitu sebesar 30 sampel. Pengambilan data penelitian dilaksanakan pada bulan Agustus 2019.

Data dianalisis menggunakan konsep produktivitas, biaya pokok produksi, dan pendapatan usahatani kedelai sebagai variabel terikat dengan metode regresi linier berganda. Variabel bebas yang digunakan dalam penelitian ini adalah variabel boneka karena variabel bebas yang digunakan berfungsi untuk mengontrol variabel terikat. Variabel bebas dalam penelitian ini adalah program Upsus dan lokasi.

Metode Estimasi yang digunakan adalah Ordinary Least Square (OLS). Secara matematis, model persamaan yang digunakan dalam penelitian ini adalah sebagai berikut:

$$
\begin{aligned}
& Y_{1 i}=\hat{a}_{0}+\hat{a}_{1} D_{1 i}+\hat{a}_{2} D_{2 i}+e_{i 1} \\
& Y_{2 i}=\hat{b}_{0}+\hat{b}_{1} D_{1 i}+\hat{b}_{2} D_{2 i}+e_{i 2} . \\
& Y_{3 i}=\hat{c}_{0}+\hat{c}_{1} D_{1 i}+\hat{c}_{2} D_{2 i}+e_{i 3} .
\end{aligned}
$$

$$
\begin{aligned}
& \text { Keterangan : } \\
& \mathrm{Y}_{1 \mathrm{i}} \quad=\text { Produktivitas (ton/ha) } \\
& \mathrm{Y}_{2 \mathrm{i}} \quad=\text { Biaya Pokok }(\mathrm{Rp} / \mathrm{kg}) \\
& \mathrm{Y}_{3 \mathrm{i}} \quad=\text { Pendapatan }(\mathrm{Rp} / \mathrm{ha}) \\
& \hat{a}, \hat{b}, \hat{c}=\text { Estimator } \\
& \mathrm{D}_{1} \quad=\text { Dummy Program Upsus } \\
& \mathrm{D}_{1}=1 \text { :Upsus } \\
& \mathrm{D}_{1}=0 \text { : Non-Upsus } \\
& \mathrm{D}_{2} \quad=\text { Dummy Lokasi } \\
& \mathrm{D}_{2}=1 \text { : Lokasi 1(Raman Utara) } \\
& \mathrm{D}_{2}=0 \text { : Lokasi 2(B.Sribhawono) } \\
& \text { e } \quad=\text { Galat }
\end{aligned}
$$

Pengaruh variabel bebas terhadap variabel terikat dapat dilihat seberapa jauh pengaruhnya dalam persamaan melalui uji statistik. Variabel dummy yang digunakan dalam model terdiri dari program Upsus dan lokasi, sedangkan variabel terikat terdiri dari produktivitas, biaya pokok produksi dan pendapatan usahatani.

Analisis yang digunakan untuk mengetahui bagaimana pengaruh variabel bebas secara bersama-sama terhadap variabel terikat menggunakan uji-F. Analisis yang digunakan untuk mengetahui secara tunggal pengaruh variabel bebas terhadap variabel terikat menggunakan uji-t.

\section{HASIL DAN PEMBAHASAN}

\section{Produktivitas (ton/ha)}

Tabel 1 menunjukan hasil regresi, nilai $\mathrm{R}$ Square sebesar 0,368 yang berarti bahwa 36,80 persen variabel produktivitas dapat dijelaskan oleh variabel Upsus dan lokasi yang dimasukan ke 
dalam model, sedangkan sisanya sebesar 63,20 persen dijelaskan oleh variabel lain yang tidak dimasukan kedalam model. Pengaruh variabel secara bersama sama dapat dilihat pada $\mathrm{F}$ hitung yang artinya variabel Upsus dan lokasi secara bersama sama berpengaruh nyata terhadap produktivitas usahatani kedelai dengan taraf nyata sebesar 1 persen.

Hasil uji t dalam mengetahui pengaruh variabel Upsus terhadap produktivitas dengan nilai koefisien sebesar 0,22 menunjukan bahwa variabel Upsus berpengaruh nyata terhadap produktivitas dengan taraf nyata 1 persen. Berdasarkan persamaan tersebut dengan mengontrol variabel lokasi, secara rata-rata produktivitas saat program Upsus lebih besar 0,22 ton/hektar daripada produktivitas Non-Upsus. Program Upsus dapat meningkatkan produktivitas kedelai sebesar 0,22 ton/hektar dengan variabel lokasi yang berperan sebagai variabel pengendali. Model empiris dapat dilihat pada Tabel 1 sebagai berikut.

Berdasarkan Tabel 1 diperoleh persamaan model sebagai berikut:

$$
\widehat{Y}=1,305+0,220 D_{1}+0,099 D_{2}
$$

Berdasarkan persamaan yang telah diperoleh, kemudian variabel bebas dimasukan kedalam model. Rata-rata produktivitas kedelai pada saat Upsus adalah sebesar 1,57 ton/ha sedangkan ratarata produktivitas kedelai Non-Upsus adalah sebesar 1,35 ton/ha. Rata-rata produktivitas kedelai pada lokasi 1 Upsus adalah 1,62 ton/ha sedangkan rata-rata produktivitas Non-Upsus sebesar 1,40 ton/ha. Rata-rata produktivitas kedelai pada lokasi 2 Upsus adalah 1,52 ton/ha sedangkan rata-rata produktivitas Non-Upsus sebesar 1,30 ton/ha. Perbandingan produktivitas kedelai Upsus dan Non-Upsus dapat dilihat pada Tabel 2.

Tabel 1. Model empiris produktivitas kedelai (ton/ha)

\begin{tabular}{lccc}
\hline Variabel Bebas & Koefisien & t-Stat & Prob \\
\hline Intersep & $1,305 * * *$ & 54,094 & 0,000 \\
Upsus & $0,220 * * *$ & 7,894 & 0,000 \\
Lokasi & $0,099 * * *$ & 3,567 & 0,000 \\
\hline F-hitung & $37,523 * * *$ & & \\
Prob (F-hitung) & 0,000 & & \\
$\mathrm{R}^{2}$ & 0,368 & & \\
Observasi & 132 & & \\
\hline
\end{tabular}

Keterangan :

*Signifikan pada taraf nyata $(\alpha) 10 \%$

**Signifikan pada taraf nyata $(\alpha) 5 \%$

***Signifikan pada taraf nyata $(\alpha) 1 \%$
Tabel 2. Rata-rata produktivitas kedelai upsus dan non-Upsus (ton/ha)

\begin{tabular}{lccc}
\hline Keterangan & Upsus & Non-Upsus & Rata-rata \\
\hline Lokasi 1 & 1,62 & 1,40 & 1,51 \\
Lokasi 2 & 1,52 & 1,30 & 1,41 \\
\hline Rata-rata & 1,57 & 1,35 & 1,46 \\
\hline
\end{tabular}

Rata-rata produktivitas kedelai pada saat Upsus lebih besar 0,22 ton/ha daripada rata-rata produktivitas Non-Upsus. Peningkatan produktivitas ini dikarenakan pada saat program Upsus, petani menerima dan menggunakan bibit unggul yang merupakan bantuan dari pemerintah yang lebih cocok dengan kondisi iklim di lokasi penelitian.

Hasil dari penelitian ini sejalan dengan penilitian Triana, Rangga dan Viantimala (2017) yang menyatakan bahwa produktivitas padi saat adanya program Upsus ikut meningkat sebesar 0,8 ton/ha di Kecamatan Seputih Raman, Kabupaten Lampung Tengah. Hal tersebut juga berkaitan dengan penelitian Rizqi, Gitosaputro dan Silviyanti (2019) yang menyatakan bahwa rata-rata prdouksi kedelai per hektar di Kecamatan Metro Barat Kota Metro sebesar 0,66 ton/ha.

Hal ini sejalan dengan penelitian Apriliana, Asmarantaka dan Winardi (2017) yang menyatakan bahwa rata rata produktivitas kedelai di Kabupaten Lamongan, Jawa Timur pada saat Upsus tahun 2015 sebesar 1,54 ton/ha. Selain itu, Safira, Hassanudin dan Viantamala (2018) juga menyatakan bahwa produktivitas kedelai saat adanya program Upsus tahun 2015 meningkat sebanyak 0,04 ton/ha dibandingkan pada saat Non Upsus tahun 2014 dengan produktivitas pada saat Upsus sebesar 1,27 ton/ha dan produktivitas NonUpsus sebesar1,23ton/ha di Kabupaten Lampung Timur.

\section{Biaya Pokok Produksi (Rp/kg)}

Tabel 3 menunjukan hasil regresi, nilai $\mathrm{R}$ Square sebesar 0,524 yang berarti bahwa 52,4 persen variabel biaya pokok dapat dijelaskan oleh variabel Upsus dan lokasi yang dimasukan ke dalam model, sedangkan sisanya sebesar 47,6 persen dijelaskan oleh variabel lain yang tidak dimasukan kedalam model. Pengaruh variabel secara bersama sama dapat dilihat pada $\mathrm{F}$ hitung yang artinya variabel Upsus dan lokasi secara bersama sama berpengaruh nyata terhadap biaya pokok usahatani kedelai dengan taraf nyata sebesar 1 persen. 
Tabel 3. Model empiris biaya pokok kedelai $(\mathrm{Rp} / \mathrm{kg})$

\begin{tabular}{lccc}
\hline Variabel Bebas & Koefisien & t-Stat & Prob \\
\hline Intersep & $4752,372 * * *$ & 74,368 & 0,000 \\
Upsus & $-870,278 * * *$ & $-11,794$ & 0,000 \\
Lokasi & $-124,929 *$ & $-1,693$ & 0,093 \\
\hline F-hitung & $70,984 * * *$ & & \\
Prob (F-hitung) & 0,000 & & \\
$\mathrm{R}^{2}$ & 0,524 & & \\
Observasi & 132 & & \\
Keterangan : & & \\
*Signifikan pada taraf nyata $(\alpha) 10 \%$ & \\
**Signifikan pada taraf nyata $(\alpha) 5 \%$ & \\
***Signifikan pada taraf nyata $(\alpha) 1 \%$ &
\end{tabular}

Hasil uji $\mathrm{t}$ dalam mengetahui pengaruh variabel Upsus terhadap biaya pokok dengan nilai koefisien sebesar 870,278 menunjukan bahwa variabel Upsus berpengaruh nyata terhadap biaya pokok dengan taraf nyata 1 persen. Model empiris dapat dilihat pada Tabel 3 .

Berdasarkan Tabel 3 diperoleh persamaan model sebagai berikut:

$\widehat{Y}=4752,372-870,278 D_{1}-124,929 D_{2} .(7)$

Berdasarkan persamaan yang telah diperoleh, kemudian variabel bebas dimasukan kedalam model. Rata-rata biaya pokok kedelai pada saat Upsus adalah sebesar Rp3.820/kg sedangkan ratarata biaya pokok kedelai Non-Upsus adalah sebesar Rp4.690/kg.

Rata-rata biaya pokok produksi kedelai pada lokasi 1 Upsus adalah Rp3.757/kg sedangkan rata-rata biaya pokok produksi Non-Upsus sebesar Rp4.627/kg. Rata-rata biaya pokok produksi pada lokasi 2 Upsus adalah Rp3.882/kg sedangkan ratarata biaya pokok produksi Non-Upsus sebesar Rp4.752/kg. Perbandingan biaya pokok produksi kedelai Upsus dan Non-Upsus dapat dilihat pada Tabel 4

Rata-rata biaya pokok usahatani kedelai pada saat Upsus lebih kecil Rp870/kg daripada rata-rata biaya pokok kedelai Non-Upsus. Pada saat Upsus, petani menerima bantuan berupa bibit unggul, pupuk Urea dan pupuk Phonska.

Tabel 4. Rata-rata biaya pokok produksi kedelai upsus dan non-upsus $(\mathrm{Rp} / \mathrm{kg})$

\begin{tabular}{llcc}
\hline Keterangan & Upsus & Non-Upsus & Rata-rata \\
\hline Lokasi 1 & 3.757 & 4.627 & 4.192 \\
Lokasi 2 & 3.882 & 4.752 & 4.317 \\
\hline Rata-rata & 3.820 & 4.690 & 4.255 \\
\hline
\end{tabular}

Tabel 5. Model empiris pendapatan usahatani kedelai ( $\mathrm{Rp} / \mathrm{ha})$

\begin{tabular}{lccc}
\hline Variabel Bebas & Koefisien & t-Stat & Prob \\
\hline Intersep & $2.979 .483^{* * *}$ & 18,603 & 0,000 \\
Upsus & $1.836 .667 * * *$ & 9,931 & 0,000 \\
Lokasi & $462.333^{* *}$ & 2,500 & 0,014 \\
\hline F-hitung & $52,437 * * *$ & & \\
Prob (F-hitung) & 0,000 & & \\
$\mathrm{R}^{2}$ & 0,448 & & \\
Observasi & 132 & & \\
\hline
\end{tabular}

Keterangan :

*Signifikan pada taraf nyata $(\alpha) 10 \%$

**Signifikan pada taraf nyata $(\alpha) 5 \%$

***Signifikan pada taraf nyata $(\alpha) 1 \%$

Hasil penelitan ini sejalan dengan Nuryanti dan Kustiari (2007) yang dalam penelitiannya menyatakan bahwa harga pokok produksi kedelai sebesar Rp3.359/kg. Hasil penelitian menunjukan bahwa pada program Upsus rata-rata produksi kedelai pada kedua lokasi penelitian mengalami peningkatan. Perbedaan biaya pokok produksi terjadi akibat adanya produksi kedelai yang lebih besar pada petani Upsus daripada petani NonUpsus.

Penurunan total biaya produksi juga terjadi pada petani Upsus dibuktikan lewat penggunaan pupuk Urea yang lebih ramah lingkungan serta penggunaan pestisida yang lebih sedikit dikarenakan tingkat serangan hama dan penyakit pada petani Upsus yang lebih sedikit dibandingkan dengan Non-Upsus.

Hasil ini selaras dengan penelitian Pamuncak, Arifin dan Kasymir (2018) yang menyatakan bahwa persentase penggunaan pupuk terhadap total biaya produksi pada tanaman kedelai sebesar 4,80 persen dari total biaya produksi sehingga penggunaan pupuk berpengaruh terhadap besaran total biaya produksi yang dikeluarkan petani.

\section{Pendapatan Usahatani (Rp/ha)}

Tabel 5 menunjukan hasil regresi, nilai $\mathrm{R}$ Square sebesar 0,448 yang berarti bahwa 44,8 persen variabel pendapatan total dapat dijelaskan oleh variabel Upsus dan lokasi yang dimasukan ke dalam model, sedangkan sisanya sebesar 55,2 persen dijelaskan oleh variabel lain yang tidak dimasukan kedalam model. Pengaruh variabel secara bersama sama dapat dilihat pada $\mathrm{F}$ hitung yang artinya variabel Upsus dan lokasi secara bersama sama berpengaruh nyata terhadap pendapatan total usahatani kedelai (taraf nyata $1 \%$ ) 
Tabel 6. Rata-rata pendapatan kedelai upsus dan non-upsus (Rp/ha)

\begin{tabular}{llll}
\hline Keterangan & Upsus & Non-Upsus & Rata-rata \\
\hline Lokasi 1 & 5.278 .482 & 3.441 .816 & 4.360 .149 \\
Lokasi 2 & 4.816 .150 & 2.979 .483 & 3.897 .816 \\
\hline Rata-rata & 5.047 .316 & 3.210 .649 & 4.128 .983 \\
\hline
\end{tabular}

Hasil uji $\mathrm{t}$ dalam mengetahui pengaruh variabel Upsus terhadap pendaptan total dengan nilai koefisien sebesar 1.836.667 menunjukan bahwa variabel Upsus berpengaruh nyata terhadap pendapatan total dengan taraf nyata 1 persen.

Berdasarkan persamaan tersebut dengan mengontrol variabel lokasi, secara rata-rata pendapatan total saat program Upsus lebih besar 1.836.667 rupiah daripada pendaptan total NonUpsus. Model empiris dapat dilihat pada Tabel 5.

Berdasarkan Tabel 5 diperoleh persamaan model sebagai berikut:

$\widehat{Y}=2.979 .483+1.836 .667 D_{1}+462.333 D_{2}(8)$

Berdasarkan persamaan yang telah diperoleh, kemudian variabel bebas dimasukan kedalam model. Rata-rata pendapatan usahatani kedelai pada saat Upsus adalah sebesar Rp5,04 juta/ha sedangkan rata-rata pendapatan usahatani kedelai Non-Upsus adalah sebesar Rp3,21 juta/ha. Ratarata pendapatan kedelai pada lokasi 1 Upsus adalah Rp5,27 juta/ha sedangkan pendapatan kedelai NonUpsus sebesar Rp3,44 juta/ha.

Rata-rata pendapatan kedelai pada lokasi 2 Upsus adalah Rp4,81 juta/ha sedangkan rata-rata pendapatan kedelai Non-Upsus sebesar Rp2,97 juta/ha. Hubungan antara poduksi dan produktivitas dengan pendapatan adalah berbanding lurus dimana apabila produksi dan produktivitas meningkat maka pendapatan akan meningkat. Perbandingan pendapatan kedelai Upsus dan Non-Upsus dapat dilihat pada Tabel 6.

Rata-rata pendapatan usahatani kedelai pada saat Upsus lebih besar Rp1,83 juta/ha daripada rata-rata pendapatan usahatani kedelai Non-Upsus. Kenaikan pendapatan usahatani kedelai ini terjadi karena adanya peningkatan produksi dan penurunan total biaya produksi pada saat program Upsus berjalan. Hal ini menjelaskan bahwa program Upsus dapat meningkatkan pendapatan usahatani kedelai di Kabupaten Lampung Timur. Penelitian ini sejalan dengan penilitian Naftaliasari, Abidin dan Khalsum (2015) yang menyatakan bahwa pendapatan total usahatani kedelai di Kecamatan Raman Utara, Kabupaten Lampung Timur pada tahun 2013 sebesar Rp7,25 juta/ha.

Hal ini berkaitan dengan penelitian Winahyu dan Nurmalina (2014) yang menyatakan bahwa pendapatan atas biaya total pada usahatani kedelai sebesar Rp680.142 /ha di desa Sukasirna, Kecamatan Sukaluyu, Kabupaten Cianjur. Selain itu, Setyawan, Marwanti dan Wuriani (2017) juga menyatakan bahwa pendapatan usahatani kedelai dalam satu musim tanam di Kecamatan Sambirejo, Kabupaten Sragen sebesar Rp837.113 /ha. Ambarita, Prasmatiwi dan Nugraha (2014) juga menyatakan bahwa pendapatan atas biaya total pada usahatani kedelai di Sekolah Lapang Pengelolaan Tanaman Terpadu (SL-PTT) Kabupaten Lampung Selatan sebesar Rp5.565.571/ha.

Hasil penelitian menunjukan bahwa pada saat Upsus rata-rata penerimaan usahatani kedelai pada kedua lokasi penelitian yang diterima petani mengalami peningkatan akibat dari kenaikan produksi kedelai dan total biaya mengalami penurunan pada saat Upsus. Penurunan total biaya produksi pada saat Upsus dibuktikan lewat penggunaan pupuk Urea yang lebih ramah lingkungan serta penggunaan pestisida yang lebih sedikit pada saat Upsus.di kedua lokasi penelitian dikarenakan tingkat serangan hama dan penyakit pada saat Upsus yang lebih sedikit dibandingkan dengan pada saat Non-Upsus.

Menurut Permentan No 03/2015 tentang ruang lingkup Upsus untuk meningkatkan produktivitas kedelai dalam mencapai swasembada kedelai terdiri dari (1) pengembangan jaringan irigasi, (2) optimalisasi lahan, (3) Gerakan Penerapan Pengolahan Tanaman Terpadu (GP-PTT) kedelai, (4) optimasi Peluasan Area Pertanaman lewat Peningkatan Indeks Pertanaman (PAP-PIP) kedelai, (5) penyediaan bantuan benih, (6) penyediaan bantuan pupuk, (7) penyediaan alat dan mesin pertanian (alsintan), (8) pengendalian Organisme Pengganggu Tanaman (OPT), dan dampak perubahan iklim, (9) asuransi pertanian, dan (10) pengawalan/pendampingan.

Kegiatan pelaksanaan Upsus dari permentan tersebut tidak semua dilaksanakan di Kabupaten Lampung Timur. Pupuk subsidi yang diterima oleh petani terdiri dari Urea, SP-36, dan Phonska. Petani juga mendapatkan bantuan berupa pupuk gratis untuk usahatani kedelai yang terdiri dari 
Urea dan Phonska. Hal ini sejalan dengan hasil penelitian Maulidiawati, Nikmatullah dan Prayitno (2018) yang menyatakan bahwa pelaksanaan program Upsus Pajale di Kecamatan Rawa Jitu Kabupaten Tulang Bawang meliputi bantuan benih, pupuk serta penyediaan alsintan. Petani penerima bantuan pupuk harus tergabung dalam kelompok tani, hal ini juga menyebabkan beberapa kelompok tani yang sudah tidak aktif untuk aktif kembali pada saat program Upsus berlangsung.

Bantuan pupuk yang diberikan kepada kelompok tani diperoleh dari distributor dengan menebus melalui bank dengan bantuan penyuluh sebagai pendamping. Dukungan penyuluh sangat berarti dalam berjalannya program Upsus karena dapat membantu petani dalam mendapatkan bantuan berupa benih dan pupuk. Pernyataan ini sesuai dengan pernyataan dalam peneitian Irsa, Nikmatullah dan Rangga (2018) yang menyatakan bahwa dukungan pendamping penyuluh pertanian dapat meningkatkan persepsi petani terhadap program Upsus Pajale. Prasetya, Effendi dan Nurmayasari (2019) juga mengutarakan dalam hasil penelitiannya bahwa peranan PPL dalam program Upsus berpengaruh nyata terhadap partisipasi petani di Kecamatan Gading Rejo Kabupaten Pringsewu.

Bantuan benih yang diberikan pada saat upsus berupa pola transfer barang yaitu bantuan fisik berupa benih kedelai yang digunakan untuk kegiatan usahatani kedelai. Bantuan benih yang diberikan dari dinas pertanian juga ada yang sempat ditinggalkan yaitu Dena 1 yang merupakan varietas baru bagi petani setempat, karena sudah tidak memungkinkan lahan ditanami varietas tersebut. Berdasarkan keterangan yang didapatkan dari petani menyatakan bahwa bantuan benih yang diberikan kualitasnya masih kalah dengan kualitas benih yang dijual di kios-kios setempat, namun petani tetap menggunakan benih bantuan guna menekan biaya produksi.

Bantuan benih kedelai ini diberikan dengan tujuan untuk meningkatkan minat petani menanam kedelai karena saat ini minat petani untuk menanam kedelai dapat dikatakan rendah. Pernyataan ini sesuai dengan hasil penelitian Pitasari, Hudoyo dan Soelaiman (2018) yang menyatakan bahwa minat petani dalam menanam kedelai di Indonesia mengalami penurunan sejak benih jagung hibrida diterapkan, dimana pada saat periode 2008 sampai 2015 terjadi penurunan minat menanam kedelai secara terus menerus, hal tersebut ditunjukan dengan angka produksi kedelai rata-rata saat itu sebesar 0,88 juta ton per tahun sedangkan produksi jagung terus mengalami peningkatan dengan adanya perkembangan benih jagung hibrida dengan rata-rata produksi pada tahun 2008-2014 telah mencapai 18,12 juta ton per tahun.

Peningkatan rata-rata produktivitas kedelai dengan adanya program upsus lewat berbagai kegiatan yang dilakukan untuk meningkatkan swasembada kedelai yaitu sebesar 16 persen dibandingkan dengan produktivitas rata-rata Non-Upsus. Peningkatan produktivitas ini diakibatkan oleh peningkatan produksi kedelai yang dihasilkan oleh petani. Semakin tinggi produksi kedelai yang dihasilkan oleh petani maka semakin tinggi pula produktivitas kedelai petani di Kabupaten Lampung Timur.

Peningkatan produksi petani akan berpengaruh terhadap biaya pokok yang dikeluarkan petani. Hal ini dikarenakan, semakin tinggi produksi yang dihasilkan dengan total biaya produksi yang tidak banyak berubah akan mengakibatkan biaya pokok atas usahatani kedelai menjadi turun. Penurunan rata-rata biaya pokok pada saat program Upsus adalah 19 persen dibandingkan dengan rata-rata biaya pokok Non-Upsus. Selain terjadi peningkatan produksi kedelai pada saat Upsus, penurunan total biaya produksi saat Upsus juga mempengaruhi penurunan biaya pokok.

Hubungan antara poduksi dan produktivitas dengan pendapatan adalah berbanding lurus dimana apabila produksi dan produktivitas meningkat maka pendapatan akan meningkat, sedangkan hubungan antara biaya pokok dengan pendapatann adalah berbanding terbalik dimana apabila biaya pokok menurun maka pendapatan akan meningkat. Peningkatan rata-rata pendapatan yang diterima petani pada usahatani kedelai di kabupaten Lampung Timur pada saat Upsus adalah 57 persen dari rata-rata pendapatan Non-Upsus. Hal ini dikarenakan adanya peningkatan produktivitas dan penurunan biaya pokok kedelai.

\section{KESIMPULAN}

Program Upsus berpengaruh nyata terhadap peningkatan produktivitas usahatani kedelai dengan taraf nyata $\alpha$ sebesar 1 persen. Rata-rata produktivitas usahatani kedelai di kedua lokasi penelitian pada saat Upsus meningkat sebesar 16 persen yaitu dari 1,35 ton/ha menjadi 1,57 ton/ha. 
Rata-rata biaya pokok produksi turun 19 persen yaitu dari Rp4.690/kg menjadi Rp3.820/kg. Ratarata pendapatan meningkat 57 persen, yaitu dari Rp3,21 juta/ha menjadi Rp5,05 juta/ha.

\section{DAFTAR PUSTAKA}

Ambarita MM, Prasmatiwi FE, dan Nugraha A. 2014. Analisis efisiensi produksi frontier dan pendapatan usahatani kedelai Sekolah Lapangan Pengelolaan Tanaman Terpadu (SL-PTT) di Kabupaten Lampung Selatan. Jurnal Jurnal Ilmu Agribisnis, 2(04): 348355.

https://jurnal.fp.unila.ac.id/index.php/JIA/artic le/view/989/895. [20 Juli 2020].

Apriliana H.,Asmarantaka, dan Winardi R. 2017. Faktor faktor yang mempengaruhi produksi dan analisis pendapatan usahatani kedelai di Kecamatan Rejoso Jawa Timur. IPB EJournal. 25(2):46-55. https://repository.ipb.ac.id/handle/123456789/ 88225. [18 Juli 2020].

Kementerian Pertanian. 2015. Peraturan Menteri Pertanian RI No. 3/Permentan/Ot.140/2/2015 Tentang Pedoman Upaya Khusus Peningkatan Produksi Padi, Jagung dan Kedelai Melalui Program Perbaikan Jaringan Irigasi dan Sarana Pendukungnya Tahun 2015. http://psp.pertanian.go.id. [20 Maret 2020].

Kementerian Pertanian. 2018. Outlook Kedelai. 2018.http://epublikasi.setjen.pertanian.go.id/ar sip-outlook/81-outlook-tanaman-pangan/682outlook-kedelai-2018. [20 Maret 2020].

Maulidiawati D, Nikmatullah D, dan Prayitno RT. 2018. Partisipasi petani dalam program upsus pajale di Kecamatan Rawajitu Kabupaten Tulang Bawang. Jurnal Jurnal Ilmu Agribisnis, $\quad$ 6(1): 65-71. https://jurnal.fp.unila.ac.id/index.php/JIA/artic le/view/2500/2184. [20 Juli 2020].

Naftaliasari T, Abidin Z, dan Khalsum U. 2015. Analisis resiko usahatani kedelai di Kecamatan Raman Utara Kabupaten Lampung Timur. Jurnal Jurnal Ilmu Agribisnis, $\quad 3(2): \quad$ 148-156. https://jurnal.fp.unila.ac.id/index.php/JIA/artic le/view/1033/938. [20 Juli 2020].

Nuryanti S., dan Kustiari R., 2007. Meningkatkan kesejahteraan petani kedelai dengan kebijakan tarif optimal. Pusat Analisis Sosial Ekonomi dan Kebijakan Pertanian. PSE Litbang Pertanian.Bogor.

http://pse.litbang.pertanian.go.id/ind/index.ph p/18. [8 Juni 2020].
Irsa R, Nikmatullah D, dan Rangga KK. 2018. Persepsi petani dan efektivitas kelompok tani terhadap program upsus pajale di Kecamatan Banjar Baru Kabupaten Tulang Bawang. Jurnal Jurnal Ilmu Agribisnis, 6(1): 2-8. https://jurnal.fp.unila.ac.id/index.php/JIA/artic le/view/2500/2184. [20 Juli 2020]

Pamuncak R, Arifin B, dan Kasymir E. 2018. Peran penggunaan pupuk pada kinerja produksi tanaman pangan Indonesia. Jurnal Jurnal Ilmu Agribisnis, 6(3): 236-241. https://jurnal.fp.unila.ac.id/index.php/JIA/artic le/view/3019/2408. [20 Juli 2020].

Pitasari Y, Hudoyo A, dan Soelaiman A. 2018. Proyeksi stokastik produksi kedelai di Indonesia. Jurnal Jurnal Ilmu AgribisniS, 6(3): 229-235. https://jurnal.fp.unila.ac.id/index.php/JIA/artic le/view/3018/2407. [20 Juli 2020].

Prasetya DY, Effendi I, dan Nurmayasari I. 2019. Peranan pendamping dan partisipasi petani dalam program upsus tanaman padi sawah di Kecamatan Gading Rejo Kabupaten Pringsewu. Jurnal Jurnal Ilmu Agribisnis, 7(2): 225-232. https://jurnal.fp.unila.ac.id/index.php/JIA/artic le/view/4249/3040. [20 Juli 2020].

Rizqi HA, Gitosaputro S, dan Silviyanti S. 2019. Partisipasi kelompok tani pada program upaya khusus padi jagung kedelai di Kecamatan Metro Barat Kota Metro. Jurnal Jurnal Ilmu Agribisnis, 7(1):99-105. https://jurnal.fp.unila.ac.id/index.php/JIA/artic le/view/3337/2558. [20 Juli 2020].

Safira A, Hasanudin T, dan Viantamala B. 2018. Efektivitas program upsus pajale terhadap peningkatan pendapatan usahatani di Kecamatan Natar

Kabupaten Lampung Selatan. Jurnal Jurnal Ilmu Agribisnis, 6(1): 6571.https://jurnal.fp.unila.ac.id/index.php/JIA/a rticle/view/3334/2555. [20 Juli 2020].

Setyawan AA., Marwanti S, dan Wuriani S. 2017. Analisis pendapatan usahatani kedelai di Kecamatan Sambirejo Kabupaten Sragen.AGRISTA, 6(4): 1-10. https://jurnal.uns.ac.id/agrista/article/view/31 22/20772. [19 Juli 2020].

Triana RS, Rangga KK, dan Viantimala B. 2017. Partisipasi petani dalam program upaya khusus peningkatan produksi padi, jagung, kedelai di Kecamatan Seputih Raman Kabupaten Lampung Tengah. Jurnal Jurnal Ilmu Agribisnis, 5(4): 446-452. https://jurnal.fp.unila.ac.id/index.php/JIA/artic le/view/1755/1558. [20 Juli 2020]. 
Jurnal Ilmu Ilmu Agribisnis: Journal of Agribusiness Science, 9(2), Mei 2021

Winahyu N., dan Nurmalina R. 2014. Pendapatan usahatani kedelai di Desa Sukasirna Kecamatan Sukaluyu Kabupaten Cianjur. IPB
E-Journal, $5(1):$

67-87. https://repository.ipb.ac.id/handle/123456789/ 78081. [19 Juli 2020]. 